International Journal of Child, Youth and Family Studies (2011) 3 \& 4: 494-509

\title{
CONSTRUCTING CRITICAL CITIZENSHIP WITH YOUNG PEOPLE: ALTERNATIVE PEDAGOGIES
}

\author{
Shannon A. Moore \\ and \\ Tyler Gegieckas, Luisa Marval, \\ Hailey McCauley, and Sarah Peloquin
}

\begin{abstract}
The authors present theoretical and empirical arguments for adopting the United Nations Convention on the Rights of the Child (or CRC) to renew the teaching of citizenship to young students from a social justice standpoint (Giroux, 2003; Giroux \& Searls-Giroux, 2004; Mitchell, 2010; Moore, 2008; Smith, 2007). The paper draws its analysis and conclusions from a descriptive, exploratory study with key participants from a 2009 rally hosted by Nobel nominee, child rights activist, and founder of Free the Children, Craig Kielburger. Four of the paper's co-authors were senior elementary students initially chosen as interviewees for the investigation and subject to traditional research protocols for minors. During data collection, however, their status shifted reflexively to include their contributions - not as objects under study or subjects of the interviewer's questions - but as co-constructors of new knowledge. Relative to the dominance of their teachers and other adult groups "engaging” their participation, this new status allowed a deeper exploration of the meanings they attached to active citizenship through an innovative dialogue (see Kellett \& Ward, 2008; Kellett, Forrest, Dent, \& Ward, 2004; also Devine, 2002). Through participatory lenses embedded within CRC principles, particularly Article 12, the analysis transcends traditional disciplinary silos to offer a critical and transdisciplinary alternative pedagogy.
\end{abstract}

Keywords: citizenship education, U.N. Convention on the Rights of the Child, transdisciplinarity, critical pedagogy

Shannon A. Moore, Ph.D. is Director, Centre for Women's Studies and Associate Professor in the Department of Child and Youth Studies at Brock University. Tyler Gegieckas, Luisa Marval, Hailey McCauley, and Sarah Peloquin were all 14year-old high school students from the Niagara Region of Ontario at the time of writing.

Correspondence concerning this article should be addressed to Dr. Shannon Moore, Department of Child and Youth Studies, Brock University, 500 Glenridge Avenue, St. Catharines, Ontario, Canada, L2S 3A1. Contact: smoore@brocku.ca 
International Journal of Child, Youth and Family Studies (2011) 3 \& 4: 494-509

Constructions of citizenship and democracy are being reshaped in this generation through the influence of social media as a political instrument. This development was acknowledged during the 2008 election of Barack Obama as President of the United States, and during the early months of 2011 through grassroots uprisings aimed at toppling regimes across various locales in North Africa and the Arabian Peninsula (beginning in Tunisia, Egypt, Yemen, and Bahrain, along with Libya and Syria at time of writing). Closer to home, Canadian federal and regional elections demonstrated an unpredictable trajectory as young people organized themselves through non-partisan “vote mobs” (Freeland, 2011). From this historic perspective, we present an argument for greater social justice and inclusion for young people through the adoption of the United Nations Convention on the Rights of the Child within citizenship curricula in Canada. While the country ratified the treaty more than two decades ago, the Canadian Senate describes it as an untapped human rights pedagogy and, as a result, children and young people as "silenced citizens" (Senate of Canada, 2007). Such a development could foster a more inclusive yet critical dialogue for and with young people to encourage political engagement and more experience in governing relations.

This argument assumes that participatory democratic traditions such as freedom of the press, freedom of speech, freedom of religion, freedom from violence, the rights to health care, peaceful assembly, and to vote work when exercised in the best interests of all citizens in contrast to social exclusion or oppressive regimes of power (see similar arguments by Moosa-Mitha, 2005; Morgan \& Streb, 2001). In addition, it includes the implicit understanding that "a theory of power is central ... to any analysis related to children’s experiences” (Devine, 2002, p. 303). Finally, this assumption has not overlooked the current contested status of citizenship for First Nations and Aboriginal peoples in this country (who were not "given" the vote until the 1960s), or that of sexual, ethnic, religious, physically-challenged, or cognitively-challenged minorities.

\section{Epistemological Lens}

It is clear in much of the human rights literature to date that theorists frequently integrate concepts related to democratic citizenship with human rights or their violation (Donnelly, 2000; Douzinas, 2006; Hawkins, 2009; see also Mitchell, 2010; O’Byrne, 2003). This paper was premised on a similar assumption that the two are inexorably linked, both positively and negatively, through human relationships. However, as Devine (2002) maintains:

If children's citizenship is to be taken seriously education for and into education must have at its core the development of political literacy among children through active decision-making and participation in all aspects of scholarly life. (p. 318)

From a rights-based perspective, young people have yet to experience their voices being heard in education, health care, or politics all that often (Senate of Canada, 2007).

Engaging young people democratically as co-constructors of knowledge was inspired by the approaches introduced by educator Mary Kellett at the Centre for Childhood Development and Learning (ChDL), Open University, England. Currently Director of the Children’s Research Centre, Kellett maintains that empowering children to execute 
International Journal of Child, Youth and Family Studies (2011) 3 \& 4: 494-509

research on issues that matter to them should be a central objective since they are experts about issues within their own lives (Kellett et al., 2004; see also http://childrens-researchcentre.open.ac.uk/; Kellett \& Ward, 2008; Mauthner, Birch, Jessop, \& Miller, 2002).

Through this approach, the current co-authors' voices became an integral theoretical thread woven throughout the analysis of other findings along with this account since, as Levison (2000) has also argued, “considering children as agents can lead to different conclusions and policy recommendations" (p. 125). This was not without some degree of consternation within the lead author's institutional Research Ethics Board ${ }^{1}$ with its historically bound notions of formal procedures to do with coercion and ethical dilemmas, and an aim more to do with the avoidance of litigation than with how one might deal with reflexivity and change on the ground (see also Mauthner et al., 2002). Our approach is counter-hegemonic to many contemporary research practices since "just as gendered perspectives have historically been ignored due to women's lack of power relative to men, so children's perspectives have been overlooked due to their lack of power vis-à-vis adults” (Levison, 2000, p. 126). As Smith (2007) also observes:

Participation rights are very important within a societal context where adult authority and power is absolute. Children's role as citizens and understanding and awareness of democracy, is determined by the extent to which their participation rights are respected. Participation rights support a sense of belonging and inclusion but more importantly teach children how they can bring about change. (p. 149)

Despite an abundance of new millennial rhetoric associated with implementing the principles and provisions of the CRC (1989), young people are less well-represented in Canada's educational, legal, policy, or legislative arenas than is the case for their contemporaries in many U.K. and European settings (Mitchell, 2003; Mitchell, 2010; Moore \& Mitchell, 2010; Osler \& Starkey, 2005; Senate of Canada, 2007). We agree with Freeman (1992) that it remains important to include children's rights with social justice and "with other rights movements (women, civil rights etc.) ... [since] 'rights' enables one to talk in terms of 'entitlements'” (Freeman, 1992, p. 41) and the power relations orchestrating traditional pedagogies. As authors, we contend this process begins with knowledge about children's rights, and particularly young people's right to participate and have a voice in decisions on matters that impact them - especially in areas pertaining to research.

\section{Ontological Lens}

The paper has been written from the standpoint of critical pedagogy first espoused by educator Paulo Freire (1970) and, thus, takes up a transdisciplinary approach to

\footnotetext{
${ }^{1}$ This study was reviewed by Brock University’s Research Ethics Board (Moore/Mitchell 08-289) with preliminary findings presented at the International Journal of the Arts and Sciences Conference in Aix-enProvence, France June 11, 2010.
} 
International Journal of Child, Youth and Family Studies (2011) 3 \& 4: 494-509

childhood studies (Moore, 2006). Giroux (2003) contends that "educators need to develop a politics and pedagogy that combine the modernist legacy of social justice, equality, freedom, and rights with late modern concerns with difference, plurality, power, discourse, identities and politics ... elements of a democratic postmodernism” (p. 54). Following on from Giroux’s perspectives, as a critical theorist the lead author reconstructs the pedagogical as political and the political as pedagogical (Freire, 1970) by directly including concerns expressed by young people regarding participatory citizenship, and integrating both disciplinary and professional lenses identified in the literature as "transdisciplinary" (Nicolescu, 1999, 2002).

The prefix "trans" simply means to go beyond; hence, "transdisciplinarity is simultaneously an attitude and a form of action” (Klein, 2004, p. 517) that fosters dialogue among specialists with a recognition of multiple new sites and forms of knowledge creation (see also Kincheloe \& McLaren, 2005; Moore \& Mitchell, 2008). It is, in the same instance, that which is between, across, and beyond all disciplines in that it fosters a unity of knowledge about our world (Nicolescu, 2005). The lead author emphasizes that this transition to transdisciplinary thinking and critical pedagogy occurred before entering the academy and after 15 years of front-line counselling practice with young people and families in Canada, Scotland, and England within mental health, education, youth justice, and out-of-home care settings. The transdisciplinary approach is also congruent with Hyslop-Margison and Thayer's (2009) contention that contrary to the reproductive model of citizenship education, a citizenship education based upon [Freirean] critical pedagogy considers society and citizenship as dynamic, fluid, and contestable constructs where fundamental social change is both imaginable and practically possible (p. 2).

Arguably, transdisciplinarity is also a significant new ontological standpoint in the context of global citizenship because it has often been adopted by multidisciplinary and interdisciplinary pedagogues (Shultz \& Jorgenson, 2009). Nicolescu (2005) furthers this argument:

The transdisciplinary education, [also] founded on the transdisciplinary methodology, allows us to establish links between persons, facts, images, representations, fields of knowledge and action to discover the Eros of learning during our entire life. The creativity of the human being is conditioned by permanent questioning and permanent integration. (p. 14)

This world view allows a new form of knowledge creation in Canadian research contexts since studies of childhood and citizenship education have most often been conducted from top-down perspectives (Howe \& Covell, 2005; Senate of Canada, 2007). Through transdisciplinary thinking, we find a "unity in diversity and diversity through unity” (Nicolescu, 2005, p. 1) that is cogent when considering parallel pedagogical implications of the local in the global, and global in the local moment. Co-construction of knowledge with young people and engaging young people as co-researchers are examples of this type of critical knowledge creation. It is well-established that individual subjects are experts in their own lives and "insiders" (Kellett \& Ward, 2008). 
International Journal of Child, Youth and Family Studies (2011) 3 \& 4: 494-509

As we leave this section, it is emphasized once again that any notion relative to a just and more inclusive "citizenship” for Aboriginal peoples across Canada must remain bracketed as a separate but integrally related investigation clearly transcending the exploratory scope of this project (see also Canadian Aboriginal News, 2009). In this, we concur with Kincheloe's (2008, as cited in Malott, 2008) observations that the vast majority of North Americans:

are absolutely unaware they are using Native land - it is just not part of Western consciousness - that we are on Native land ... It seems rather obvious [even though nobody seems to think about it] that a central dimension of any critical pedagogy has to deal with the subject of indigeneity, and it is something very few critical scholars are aware of or interested in. (pp. 153-154)

For a more in-depth discussion, Stasiulis (2002a) outlines the contours of this national amnesia and its harvest of contested notions of citizenship inherited from Canada's colonial past through to its present-day "treaty federalism and treaty citizenship" (pp. 369-370).

\section{Methodological Lens}

The original study was framed by this research question: What are some of the critical issues for young people as they attempt to exercise their rights to participatory citizenship in Canada and beyond? Contributions were made by the co-authors of this paper in response to the question after attending a youth rally held at Brock University in May, 2009. Be the Change: A Niagara-wide Youth Leadership Conference on Global Citizenship was hosted by the campus Free the Children Action Group (see www.freethechildren.com) which is formally affiliated with the larger organization established in Canada in 1995 by then 12-year-old Craig Kielburger. Sixteen years later, Free the Children has become an international non-governmental organization (C. Kielburger \& M. Kielburger, 2006). The Brock University chapter succeeded with a twoyear fundraising drive to co-host the rally, and this included successfully collaborating with a group of 15 high school students employed by the Regional Public Health Authority (http://www.niagararegion.ca/news/nov1820102.aspx).

The May, 2009 event was attended by over 500 elementary, high school and university-aged delegates, each motivated to hear Craig speak and to participate in workshops on themes of global citizenship and activism (Dickson, 2010). As an organization, Free the Children was founded on social justice principles and based upon social entrepreneurship wherein critical citizenship is enacted as a process/activity, and where social values of local and global change are generated by young people themselves. There are four common themes shaping social entrepreneurship that distinguish these activities from corporate enterprise.

1. Emphasis on "social goals" as opposed to economic gains;

2. The social activist role played by the social entrepreneur;

3. Elements of entrepreneurship and innovation; and, 
International Journal of Child, Youth and Family Studies (2011) 3 \& 4: 494-509

4. Creating and using economic profit as a means to solve the social problem rather than as an end in itself. (Trivedi, 2010, p. 68)

Co-founder of Free the Children, Marc Kielburger, underlines the philosophy of Free the Children: "if we can give people the opportunity to make choices that support a more sustainable lifestyle, it is possible to do and generate profits. In fact, that classic win-win is the very cornerstone of the entire social economy" (as cited in Wingrove, 2010, March 20, p. F6).

\section{Discussion: Towards an Alternative Pedagogy}

The following section draws further upon relevant literature and citations are interspersed with the co-authors' written accounts of their observations from the conference and their reflections on the research question. Historically, childhood theories have been shaped by adultist political, ideological, and disciplinary perspectives that have silenced young people by constructing them as docile citizens-in-waiting (Raby, 2005; Mitchell, 2010; Moore \& Mitchell, 2008, 2009; Stasiulis, 2002a, 2002b). As highlighted in the introduction, traditional approaches to citizenship pedagogies in Canada also adopt this cognitive and developmental psychology orientation towards civics curricula (see, for example, Howe \& Covell, 2005, p. 123).

Today, critical pedagogues are urging educators (and other adults in authority) to also value the critical capacities of young citizens and to understand that educational sites are vital spaces in which to affect social struggles positively (Giroux, 2008). From the standpoint of Freirean pedagogy, a critical discussion of children's human rights in the classroom offers educators and students new potential for enacting a dynamic citizenship, one that at the same moment recognizes formal political status as it engages in democratic teaching and learning relations (see also Ben-Arieh \& Boyer, 2005; Devine, 2002; Stasiulis, 2002a, 2002b; Tomaševski, 2006).

This shift towards valuing young people's contributions in shaping educational and democratic participation in the classroom and in civil society is reinforced by the organizing principles of the CRC, rather than traditional approaches that treat young people as citizens-in-waiting. The treaty offers a framework for this type of alternative approach towards teaching democratic traditions premised upon Article 42 to "make the principles of the CRC widely known" to young people, educators, and policy-makers alike. Indeed, during a 2002 interview with one of the treaty's 1979/89 U.N. and nongovernmental negotiators, Mitchell (2005) found this text was conceived by consensus and added in late going as an "international compliance indicator" (pp. 324-325; see also UN General Assembly, 1994).

As Giroux (2008) explains, “dialogue, thoughtfulness and critical exchanges” are fostered when we understand that education is "more than an investment opportunity" and that "citizenship is more than conspicuous consumption, learning is more than preparing for a job” (p. 65). Co-author Tyler Gegieckas reinforces this shift towards 
International Journal of Child, Youth and Family Studies (2011) 3 \& 4: 494-509

newer constructions of citizenship and towards more participatory expressions of “engagement”.

Ever since I was a little kid, I was always told that I couldn't do anything. Tyler don't touch that, Tyler don't do that. Over and over. But global citizenship is something that I'm not going to be told no ... Global Citizenship means to me that somebody is willing to make a difference and take a stand. Somebody that instead of buying needless things, sponsors somebody from a different county who is less fortunate. Somebody instead of letting kids pick on somebody sticks up for that person.

Every little thing helps and makes you a global citizen ... I think people these days are too concerned with their own personal issues ... Who cares if you don't have a dress for a movie, what we should be caring about is whether people have enough to eat in places all over the world. Now a global citizen cares about that ... I am a global citizen and have already started doing things.

Similar to Giroux’s arguments and Tyler’s observations, Hyslop-Margison and Thayer (2009) contend that "our role in education is not to prepare students for a new economic reality designed by others, but to prepare them to shape social reality in more progressive and socially just sorts of ways” (p. X). Education is seen as the cornerstone for understanding and experiencing citizenship rights (Moore, 2008; Moore \& Mitchell, 2008; Tomaševski, 2006) since basic knowledge of civic, social, and political rights is the most basic human right of all (also Arendt, 1970; Freeman, 2007). Moosa-Mitha (2005) extends this analysis further:

Children's difference from the adult "norm” assumed of citizens in liberal models of citizenship results in overlooking children's citizenship rights through a construction of children as "not-yet-citizens". Alternative models of citizenship that centre on "difference" of social identities such as gender, race sexuality, class, and so on, offer possibilities of defining citizenship in ways that take their rights and status as citizens seriously on the basis, rather than the exclusion, of their identity as children. (pp. 369-370)

Such criticality permits the uncovering of expressions of active citizenship within institutional power relations. Educational sites, particularly for young people, have emancipatory potential and pedagogues have the potential to mentor autonomy, political agency, and social change. Nevertheless, as Giroux (2003) argues:

[M]any educators have failed to take seriously Italian Marxist Antonio Gramsci’s insight that "[e]very relationship of hegemony is necessarily an educational relationship" with its implication that education as a cultural pedagogical practice takes place across multiple sites as it signals how, within diverse contexts, education makes us both subjects of and subject to relations of power. (p. 64) 
International Journal of Child, Youth and Family Studies (2011) 3 \& 4: 494-509

Hannah Arendt underscored this argument when she petitioned us to understand education as linked to democracy and the power to prepare our children to take responsibility to renew a common world (as cited in Giroux, 2010, p. 1). Co-author Luisa Marval affirms this optimistic notion that instilling hope for change and appropriating the tools necessary for greater social justice can nurture critical citizenship:

If we open our minds and our hearts to others, it will almost naturally follow that our actions will be those of a global citizen ... We should never underestimate the importance of simply educating others about global issues and ways of becoming involved ... No matter how young or old we are, there are innumerable ways to make a difference. However, this doesn't mean that each of us must go overseas to build houses. We have to start in our own communities.

Global citizens value diversity, are aware of and want to abolish social injustice and they care for fellow humans as well as human rights and dignity. I strongly feel that we should see differences as a strength and not weakness and that we should celebrate differences. After all, we all have different styles, traits and characteristics, even without our own culture, so why shun diversity?

Concerning social injustice, a global citizen works hard to eradicate cruelty, unjust laws and practices and to provide freedom and justice for all. Human rights and equality are other relevant issues that global citizens must be aware of. All humans should be treated equally regardless of their sex, colour, religion or race. As the old proverb says, "No human is more human than another human."

For much of the past half century, Canadians have enjoyed an international reputation as being human rights champions through their founding membership in the United Nations (United Nations International Children's Emergency Fund [UNICEF], 2009) and as early promoters of the CRC (Mitchell, 2000, 2005). This claim is no longer tenable since the current political dynamics in the nation and the actual experience of exclusionary forms of citizenship for those under the age of 18 clearly reflect successive governmental violations through ideological misinterpretations (see Howe \& Covell, 2005, 2007; Mitchell, 2010; United Nations Committee on the Rights of the Child, 1995, 2003). Generalized fears of young people in Canada have been coupled with "dominant Western notions of childhood that fetishize innocence and attribute passivity and incompetence to children” (Stasiulis, 2002b, p. 507). This ideological and political stance propels adultist institutions to favour power and control over participation (Moore \& Mitchell, 2009; Mitchell, 2010; see also Scraton, 1997). Although still widely misunderstood by childhood academics and advocates alike (Mitchell, 2010), serious efforts to implement the CRC in Canada could still have a:

profound impact on real children's lives ... children's rights are being pushed to the side and even violated ... one only needs to take a brief survey of the issue of child poverty, or the situation of Aboriginal or special needs children to realize that this is true. (UNICEF, 2009, p. 14) 
International Journal of Child, Youth and Family Studies (2011) 3 \& 4: 494-509

Co-author Hailey McCauley confirms this argument as she describes the way from her perspective - children's rights, citizenship, and social justice relate:

I have a voice, I have a right, I have freedom but there are so many children out there that don't have a right and don't have their voices heard when they should. Just knowing some child out there, any age, is working instead of playing, having fun and enjoying their life and may have never gone to school, so they can't read or write. It's unfair and I want to help change that.

Even if I can only do something small, I know it can and will make a big difference in somebody else's life. I want to help make a difference because I am fortunate, there are so many children that don't have anything when I have so much. I have clean drinking water, yet so many people out there don't. There is so much poverty everywhere, even in my own local community, it's so unreal and heartbreaking. I just can't sit back and do nothing. I want to help, I want to make a difference, and I want to be the change.

Today, young people form the largest generation yet seen, and are at the epicentre of a world that has changed in unimaginable ways, particularly over the past two decades (UNICEF, 2009, p. 63). Young people can offer creative solutions as they analyze challenges from their fresh points of view, as co-author Sarah Peloquin expresses in the following:

When you hear the words "global citizen" you probably think, "I am a global citizen because I live on Earth”. A global citizen is simply ... someone who lives on the Earth. Whereas an active global citizen is someone who not only lives on Earth but truly tries to make it a better place ...

In a way this is a lot like being an active global citizen because the world is filled with problems and we are reminded of that everyday but most of the time we just choose to close the door on them. I wasn't all that aware of being an active global citizen until I started hearing both of my teachers use the saying ... "If you are not part of the solution you are part of the problem." This really got me thinking by making me realize that since I wasn't involved in helping the world's problems I was part of them.

Young people often seek opportunities to experience how local initiatives can contribute to meaningful change - a change that for many starts with the community through small acts, as Sarah Peloquin describes above. This process of creating space for the voice of young people to effect meaningful change begins with restructuring adult-child power relations. As Devine (2002) has also concluded: "providing children with access to a greater range of authoritative resources ... would enable them to see that their voices really count, paving the way for a more active citizenry of children now as well as into their future adult years” (p. 318). 
International Journal of Child, Youth and Family Studies (2011) 3 \& 4: 494-509

\section{Concluding Thoughts}

If we accept that knowledge of human rights is the most basic right of all, then education about human rights as a necessary prerequisite to a just civil society becomes an obvious inference. Human rights and citizenship are indelibly linked: The expression of human rights is a dynamic of citizenship that enacts citizenship as a formal legal status denoting belonging to a group (Ben-Arieh \& Boyer, 2005; Stasiulis, 2002a, 2002b). This paper offers an exploratory analysis of citizenship pedagogy through a social justice lens. The authors present an argument for starting with knowledge of the Convention on the Rights of the Child to establish an alternative pedagogy to the traditional top-down adultist perspectives so typically found in Canadian classrooms. This was facilitated through transdisciplinary thinking and the engagement of a group of young people in Canada as co-constructors of knowledge.

Over the past two decades, it has been consistently documented that the majority of Canadian students of any age know little to nothing about their human rights, as articulated within the CRC (Senate of Canada, 2007; also Howe \& Covell, 2005; Mitchell, 2005; Mitchell, 2010; Moore \& Mitchell, 2010). That most Ministries of Education have chosen not to make the teaching of human rights to young people compulsory in their provincial curricula is a direct violation of CRC Article 42, and furthermore, contravenes key elements of the rights to education found in Articles 28 and 29 (United Nations Committee on the Rights of the Child, 1995, 2003). Indeed, many young people only hear about their Convention rights for the first time in post-secondary institutional venues such as the Be the Change conference. Full realization of the citizenship rights of young people simply is "not there yet" in practice (see UNICEF, 2009, p. 14).

In Canada, as in many countries that have ratified the CRC, power relations impede young people from active engagement as critical citizens capable of enacting solutions due to their less well-developed maturity. These power relations are impacted further by adultist ideologies of childhood: standardized developmental trajectories; child as future investment; child and young person as incompetent, innocent, vulnerable, or deviant (Moore \& Mitchell, 2010). Kellett et al. (2004) contend that, "From a rightsbased agenda, the perspective of children as social actors places them as a socially excluded minority group struggling to find a voice” (p. 330). They further observe: "Articles 12 and 13 of the UNCRC require that children should be informed, involved and consulted about all activities that affect their lives” (p. 329). As Shultz and Jorgenson (2009) argue:

This [kind of] education is a call to change the way things are done; to strive toward education at its best that is based on inquiry, critical thinking, and deep engagement that results in changes in learning, action, and both local and global social conditions. This education does not belong to any one faculty or discipline or to either formal or non-formal education but should be embedded within each in ways that extend and support the work of global citizenship education. (p. 2) 
The active participation of young people is an essential requisite to citizenship, and this sensibly may be nurtured through engagement in decision-making within educational contexts. The reinterpretation of traditional adultist power relations could be facilitated within an education that includes the human rights of young people for policy-makers, educators, and all levels of students, in conjunction with meaningful responses to the views and participation of young people. 
International Journal of Child, Youth and Family Studies (2011) 3 \& 4: 494-509

\section{References}

Arendt, H. (1970). On violence. New York: Harcourt Brace and Co.

Ben-Arieh, A., \& Boyer, Y. (2005). Citizenship and childhood: The state of affairs in Israel. Childhood, 12(1), 33-53.

Canadian Aboriginal News. (2009, September 14). Discrimination Against first Nations Filed in the Human Rights Commission. Retrieved from:

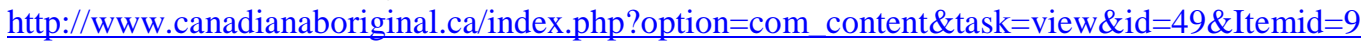

Devine, D. (2002). Children's citizenship and the structuring of adult-child relations in the primary school. Childhood, 9(3), 303-320.

Dickson, E. (2010, November 30). Brock hosts “Be the Change” Conference. The Brock Press Online. Retrieved from: http://media.www.brockpress.com/media/storage/paper384/news/2010/04/06/News/Brock.Hosts.b e.The.Change.Conference-3900468.shtml

Donnelly, J. (2008). Human rights: Both universal and relative. Human Rights Quarterly, 30(1), 194-204.

Douzinas, C. (2006). Postmodern just wars and the new world order. Journal of Human Rights, 5, 55-75.

Freeland, C. (2011). Calgary mayor gives a twitter revolution lesson. Globe and Mail. Retrieved from http://m.theglobeandmail.com/report-on-business/commentary/chrystia-freeland/calgary-mayorgives-a-twitter-revolution-lesson/article1965627/?service=mobile

Freeman, M. (1992). The limits of children's rights. In M. Freeman \& P. Veerman (Eds.), The ideologies of children's rights (pp. 29-46). Dordrecht, Netherlands: Kluwer Academic.

Freeman, M. (2007). Why it remains important to take children's rights seriously. The International Journal of Children's Rights, 15, 5-23.

Freire, P. (1970). Pedagogy of the oppressed. New York: Herder and Herder.

Giroux, H. A. (2003). The abandoned generation. New York: Palgrave Macmillan.

Giroux, H. A. (2008). Disabling the future: Youth and the politics of disposability. In S. A. Moore \& R. C. Mitchell (Eds.), Power, pedagogy and praxis: Social justice in the globalized classroom (pp. 55-72). Rotterdam: Sense Publishers. 
International Journal of Child, Youth and Family Studies (2011) 3 \& 4: 494-509

Giroux, H. A. (2010, 15 February). Democracy and the threat of authoritarianism: Politics beyond Barack Obama. Truthout/OP-ED. Retrieved from: http://www.truthout.org/democracy-and-threat-authoritarianism-politics-beyond-barackobama56890

Giroux, H. A., \& Searls Giroux, S. (2004). Take back higher education - Race, youth and the crisis of democracy in the post-civil rights era. New York: Palgrave Macmillan.

Hawkins, C. (2009). Global citizenship: A model for teaching universal human rights in social work education. Critical Social Work, 10. Retrieved from: http://www.uwindsor.ca/criticalsocialwork/global-citizenship-a-model-for-teaching-universalhuman-rights-in-social-work-education

Howe, R. B., \& Covell, K. (2005). Empowering children - Children's rights education as a pathway to citizenship. Toronto: University of Toronto Press.

Howe, R. B., \& Covell, K. (2007). A question of commitment - Children's rights in Canada. Waterloo, ON: Wilfrid Laurier University Press.

Hyslop-Margison, E. J., \& Thayer, J. (2009). Teaching democracy - Citizenship education as critical pedagogy. Rotterdam: Sense Publishers.

Kellett, M., \& Ward, B. (2008). Children as active researchers: Participation and power sharing. In S. A. Moore \& R. C. Mitchell (Eds.), Power, pedagogy and praxis: Social justice in the globalized classroom (pp. 91-103). Rotterdam: Sense Publishers.

Kellett, M., Forrest, R., Dent, N., \& Ward, S. (2004). "Just teach us the skills please, we'll do the rest”: Empowering ten-year-olds as active researchers. Children \& Society, 18(5), 329-343.

Kielburger, C., \& Kielburger, M. (2006). Me to we: Finding meaning in a material world. Toronto: Wiley and Sons.

Kincheloe, J. (2008). The past, present, and future of critical pedagogy: With Joe Kincheloe. In C. S. Malott (Ed.), A call to action: An introduction to education, philosophy, and Native North America (pp. 153-162). New York: Peter Lang Publishers.

Kincheloe, J., \& McLaren, P. (2005). Rethinking critical theory and qualitative research. In N. K. Denzin \& Y. S. Lincoln (Eds.), The Sage handbook of qualitative research (3rd ed., pp. 303-342). Thousand Oaks, CA: Sage Publishers Ltd.

Klein, J. T. (2004). Prospects for transdisciplinarity. Futures, 36(4), 515-526. 
International Journal of Child, Youth and Family Studies (2011) 3 \& 4: 494-509

Levison, D. (2000). Children as economic agents. Feminist Economics, 6(1), 125-134.

Malott, C. S. (2008). A call to action: An introduction to education, philosophy, and Native North America. New York: Peter Lang Publishing.

Mauthner, M., Birch, M., Jessop, J., \& Miller, T. (Eds.). (2002). Ethics in qualitative research. London: Sage Publishers.

Mitchell, R. C. (2000). Implementing children's rights in British Columbia using the population health framework. The International Journal of Children's Rights, 8(4), 333-349.

Mitchell, R. C. (2003). Ideological reflections on the DSM-IV-R (or Pay no attention to that man behind the curtain, Dorothy!). Child and Youth Care Forum, 32(5), 281-298.

Mitchell, R. C. (2005). Postmodern reflections on the UNCRC: Towards utilising Article 42 as an international compliance indicator. The International Journal of Children's Rights, 13(3), 315-331.

Mitchell, R. C. (2010). Who’s afraid now? Reconstructing Canadian citizenship education through transdisciplinarity. The Review of Education, Pedagogy, and Cultural Studies, 32, 37-65.

Moore, S. A. (2006). Transdisciplinary approaches to critical multicultural pedagogy in Canadian higher education. In D. Zinga (Ed.), Navigating multiculturalism: Negotiating change (pp. 126-139). Newcastle: Cambridge Scholars Press.

Moore, S. A. (2008). Social justice and education in a world fit for children? In J. A. Kentel \& A. Short (Eds.), Totems and taboos: Risk and relevance in research on teachers and teaching (pp. 17-29). Rotterdam: Sense Publishers.

Moore, S. A., \& Mitchell, R. C. (Eds.). (2008). Power, pedagogy and praxis: Social justice in the globalized classroom. Rotterdam: Sense Publishers.

Moore, S. A., \& Mitchell, R. C. (2009). Rights-based restorative justice: Evaluating compliance with international standards. Youth Justice, 9, 27-43.

Moore, S. A., \& Mitchell, R. C. (2010). Theorising rights-based restorative justice: The Canadian context. The International Journal of Children's Rights, 19(1), 81-105.

Moosa-Mitha, M. (2005). A difference-centred alternative to theorization of children's citizenship rights. Citizenship Studies, 9(4), 369-388.

Morgan, W., \& Streb, M. (2001). Building citizenship: How student voice in servicelearning develops civic values. Social Science Quarterly, 82(1), 154-169. 
International Journal of Child, Youth and Family Studies (2011) 3 \& 4: 494-509

Nicolescu, B. (1999, April). The transdisciplinary evolution of learning. Paper presented to the Symposium on Overcoming the Underdevelopment of Learning held at the Annual Meeting of the American Educational Research Association, Montreal, Canada.

Nicolescu, B. (2002). Manifesto of transdisciplinarity. New York: State University of New York Press.

Nicolescu, B. (2005, September). Transdisciplinarity - Past, present and future. Paper presented to the Palestra apresentada no II Congresso Mundial de Transdisciplinaridade, Vila Velha/Vitória, SC, Brasil. Retrieved from: http://cetrans.com.br/novo/textos/transdisciplinarity-past-present-and-future.pdf

O’Byrne, D. J. (2003). Human rights - An introduction. London: Pearson Education.

Osler, A., \& Starkey, H. (2005). Changing citizenship - Democracy and inclusion in education. London: Open University Press.

Raby, R. (2005). Polite, well-dressed and on time: Secondary school conduct codes and the production of docile citizens. Canadian Review of Sociology and Anthropology, 42, 71-92.

Scraton, P. (Ed.). (1997). “Childhood” in “crisis”? London: Routledge.

Senate of Canada. (2007). Children: The silenced citizens. Ottawa: Standing Senate Committee on Human Rights, Government of Canada. Retrieved from: http://www.parl.gc.ca/39/1/parlbus/commbus/senate/Com-e/huma-e/rep-e/rep10apr07-e.htm

Shultz, L., \& Jorgenson, S. (2009). Global citizenship education in post-secondary institutions: A review of the literature. Edmonton: University of Alberta.

Retrieved from: http://www.uofaweb.ualberta.ca/uai_globaleducation/pdfs/gce_lit_review.pdf

Smith, A. (2007). Children and young people's participation rights in education. The International Journal of Children's Rights, 15(1),147-164.

Stasiulis, D. (2002a). Introduction: Reconfiguring Canadian citizenship. Citizenship Studies, 6(4), 365-375.

Stasiulis, D. (2002b). The active child citizen: Lessons from Canadian policy and the children’s movement. Citizenship Studies, 6(4), 507-538.

Trivedi, C. (2010). Towards a social ecological framework for social entrepreneurship. The Journal of Entrepreneurship, 19, 63-80.

Tomaševski, K. (2006). The state of the right to education worldwide - Free or fee. 2006 global report. Retrieved from: http://www.katarinatomasevski.com/ 
International Journal of Child, Youth and Family Studies (2011) 3 \& 4: 494-509

United Nations Committee on the Rights of the Child. (1995). Concluding observations/ comments: Canada. Geneva: United Nations.

United Nations Committee on the Rights of the Child. (2003). Concluding observations/ comments: Canada. Geneva: United Nations.

United Nations Convention on the Rights of the Child. (1989). New York, Geneva: United Nations.

United Nations General Assembly. (1994, December). Resolution 49/184. United Nations decade for human rights education 1995-2004 and public information in the field of human rights - No. 1. New York: United Nations.

United Nations International Children's Emergency Fund. (2009). Not there yet: Canada's implementation of the general measures of the Convention on the Rights of the Child. Florence, Italy: Innocenti Research Centre and UNICEF Canada.

Wingrove, J. (2010, March 20). Marc and Craig Kielburger's do-gooding social enterprise. The Globe and Mail. Retrieved from:

http://www.theglobeandmail.com/news/national/marc-and-craig-kielburgers-do-gooding-socialenterprise/article1506256/ 